\title{
Ecophysiological responses of dual-purpose wheat originating from different cutting management systems
}

\section{Respostas ecofisiológicas de trigo duplo propósito originado de diferentes manejos de corte}

\author{
Felipe Koch ${ }^{1 *}$; Ivan Ricardo Carvalho²; Vinícius Jardel Szareski³; \\ Gustavo Henrique Demari ${ }^{1}$; Manoela Andrade Monteiro' ${ }^{1}$; João Roberto Pimentel ${ }^{3}$; \\ Maicon Nardino ${ }^{4}$; Tiago Pedós; Velci Queiróz de Souza ${ }^{6}$; Tiago Zanatta Aumonde ${ }^{5}$
}

\begin{abstract}
Wheat is one of the most cultivated cereals worldwide. Some wheat genotypes may be used for dual purposes that is, in the production of animal fodder and grains. The objective of this study was to compare the growth, partitioning of assimilates, and seed vigor expression of dual-purpose wheat cultivars originating from seeds produced by plants subjected to different cutting management systems. Dual-purpose wheat seeds in the vegetative period were used for this study; these were obtained from the cultivar BRS Umbu produced by plants subjected to different cutting management systems. The experimental design was completely randomized in a factorial scheme, with four replications. The treatments comprised a combination of four seed production systems (one, two, and three cuts) and eight planting seasons $(10,20,30,40,50,60,70$, and 80 days after emergence [DAE]). Total dry-mass, drymass production rate, relative growth rate, net assimilation rate, leaf area index, solar energy conversion efficiency, dry-mass partitioning, seedling emergence in the field, and emergence speed index were evaluated. Data regarding seedling emergence and emergence speed index were adjusted by orthogonal polynomials. Primary growth data were evaluated from the simple logistic equation. From 60 DAE, an inversion of the values of total dry-mass was observed, and the maximum values were observed in plants from seeds produced without cutting management. The highest dry-mass production rates were noted for plants produced by seeds of plants not subjected to cutting management. The highest relative growth rates were noted among plants originating from seeds produced by plants subjected to three- and two-cut treatments. The net assimilation rate was higher in plants originating from seeds produced from plants subjected to cutting management systems. The highest values of emergence were observed for seeds obtained from the three-cut treatment. Similarly, an increase in the values of emergence speed index was observed in seeds from plants subjected to one-cut treatment. Dual-purpose wheat cultivars originating from seeds produced in the absence of cutting management presented higher total dry-mass, dry-mass production rate, and relative growth rate. The net assimilation rate was higher in plants from seeds produced with cutting management systems. Plants produced from seeds subjected to the threecut production management resulted in more vigorous seeds.
\end{abstract}

Key words: Growth analysis. Liquid assimilation rate. Triticum aestivum (L.). Seed vigor.

\footnotetext{
${ }^{1}$ Discentes do Curso de Doutorado, Programa de Pós-Graduação em Ciência e Tecnologia de Sementes, Departamento de Fitotecnia, Universidade Federal de Pelotas, UFPel, Pelotas, RS, Brasil. E-mail: felipe.koch@hotmail.com; deolhonaagricultura@gmail. com; manu agro@hotmail.com

2 Discente do Curso de Doutorado, Programa de Pós-Graduação em Agronomia, UFPel, Pelotas, RS, Brasil. E-mail: carvalhoirc@ gmail.com

3 Discentes do Curso de Mestrado, Programa de Pós-Graduação em Ciência e Tecnologia de Sementes, Departamento de Fitotecnia, UFPel, Pelotas, RS, Brasil. E-mail: viniciusszareski@gmail.com; jrobertopimentel@hotmail.com

${ }^{4}$ Prof. Dr., Universidade Federal de Santa Maria, UFSM, Frederico Westphalen, RS, Brasil. E-mail: nardinomn@gmail.com

${ }_{5}^{5}$ Profs. Drs., Universidade Federal de Pelotas, UFPEL, Pelotas, RS, Brasil. E-mail: tiago.pedo@gmail.com; tiago.aumonde@ gmail.com

${ }^{6}$ Prof. Dr., Universidade Federal do Pampa, UNIPAMPA, Dom Pedrito, RS, Brasil. E-mail: velciq@gmail.com

* Author for correspondence
} 


\section{Resumo}

O trigo é um dos cereais mais cultivados em todo o mundo, alguns genótipos podem apresentar dupla aptidão, ou seja, capacidade de produzir forragem para animais e grãos. O trabalho teve como objetivo comparar o crescimento, a partição de assimilados e a expressão do vigor de sementes de trigo duplo propósito originado a partir de sementes produzidas por plantas submetidas a diferentes manejos de corte. Foram utilizadas sementes de trigo duplo propósito da cultivar BRS Umbu, produzidas por plantas submetidas a diferentes manejos de corte no período vegetativo. O delineamento experimental foi inteiramente casualizado em esquema fatorial, com quatro repetições. Os tratamentos consistiram na combinação de quatro manejos de produção de sementes (sem; um; dois e três cortes) e oito épocas de coleta de plantas $(10 ; 20 ; 30 ; 40 ; 50 ; 60 ; 70$ e 80 dias após a emergência (DAE). Foram avaliadas a massa seca total, taxa de produção de massa seca, taxa de crescimento relativo, taxa assimilatória liquida, índice de área foliar, eficiência de conversão de energia solar, partição de massa seca, emergência de plântulas em substrato e índice de velocidade de emergência de plântulas. Os dados referentes à emergência e índice de velocidade de emergência de plântulas foram ajustados por polinômios ortogonais. Dados primários de crescimento foram avaliados a partir da equação logística simples. A partir dos $60 \mathrm{DAE}$, verificou-se a inversão dos valores de massa seca total, onde os máximos foram observados em plantas provenientes de sementes produzidas sem manejo de corte. Os maiores valores de taxa de produção de massa seca foram determinados em plantas produzidas por sementes de plantas não submetidas ao corte no seu manejo de produção. Os maiores valores da taxa de crescimento relativo foram obtidos em plantas originadas de sementes produzidas por plantas submetidas a três e dois cortes, assim como a taxa assimilatória líquida, que foi superior em plantas originadas de sementes produzidas a partir de plantas submetidas aos manejos com corte. Os maiores valores de emergência foram obtidos em sementes do tratamento que constou de três cortes durante o manejo de produção, de maneira similar, o índice de velocidade de emergência demonstrou acréscimo nos valores a partir do tratamento que constou de um corte durante o manejo de produção de sementes. Plantas de trigo duplo propósito originadas de sementes produzida na ausência de corte atingem maior alocação de massa seca total, taxa de produção de massa seca e taxa de crescimento relativo. A taxa assimilatória líquida é superior em plantas provenientes de sementes produzidas com manejo de corte. Sementes mais vigorosas são obtidas quando produzidas por plantas provenientes do manejo de produção com três cortes.

Palavras-chave: Análise de crescimento. Taxa assimilatória líquida. Triticum aestivum (L.). Vigor de sementes.

Wheat (Triticum aestivum L.) belongs to the family Poaceae. Some genotypes may have aptitude for dual-purpose cropping - that is, they can be used for animal fodder production as well as grain production. Wheat is one of the most cultivated cereals in the world, and its cultivation in Brazil is spread across several regions, mainly in southern Brazil, which alone contributes to approximately $95 \%$ of the estimated 5.9 million tons of grains produced in Brazil (CONAB, 2015).

Cutting management influences plant growth and development, because the removal of the shoot promotes an abrupt reduction in the photosynthetically active leaf area, modifying the production and partition of the assimilates between plant structures (GONDIM et al., 2008).
Dual-purpose wheat cropping is characterized by rapid establishment; long vegetative and short reproductive periods, which result in a higher number of cuts; superior grazing tolerance; excellent fodder bromatological quality; and adequate animal acceptability (MARTIN et al., 2010). It is considered a forage alternative because it facilitates crop-livestock integration and crop rotation, and fulfills the as-yet unmet requirement for autumnal fodder in the southern region of Brazil (MARTIN et al., 2010).

Cutting management in the production of dualpurpose wheat cultivars can negatively influence plant growth and physiology; moreover, it can also adversely affect seed quality, physiological potential, seedling development, and plant establishment (FORSTHOFER et al., 2006). 
Growth analysis may be performed to evaluate plant performance and management under different environmental conditions, and also elucidates the individual contributions of different physiological processes to growth under various conditions (RADFORD, 1967). This technique is the first step in the interpretation and analysis of primary production and allows evaluation of the competitive capacity or acclimatization of plants under different environmental conditions (LOPES; LIMA, 2015).

Thus, dual-purpose wheat cultivars subjected to different cutting management strategies may show differential performance with regard to seed vigor expression, as well as modified growth rates depending on dry-mass allocation. Therefore, the objective of this study was to evaluate the growth, partition of assimilates, and seed vigor expression of dual-purpose wheat seeds from plants subjected to different cutting management systems.

The experiment was carried out in an experimental area in the Laboratory of Seeds of the Department of Phytotechnology, Graduate Program in Seed Science and Technology, Federal University of Pelotas $\left(31^{\circ} 52^{\prime} \mathrm{S}-52^{\circ} 21^{\prime} \mathrm{W}\right.$, altitude: $\left.13 \mathrm{~m}\right)$. According to Köppen's climate classification, the climate of the study region is type $C f a$, characterized as temperate with well-distributed rains and hot summer. The solar radiation and temperature data during the experimental period were retrieved from the bulletin of the Agroclimatological Station of Pelotas - RS, Brazil, located $100 \mathrm{~m}$ from the study area.

The average maximum and minimum temperatures during plant development were 22.5 and $14{ }^{\circ} \mathrm{C}$, respectively (Figure 1a), whereas solar radiation remained constant up to 60 days after emergence (DAE), after which it showed an increasing trend until the end of the plant cycle (Figure 1b).

For seed production in the experiment, the BRS Umbu cultivar was sown in a no-tillage system, using $250 \mathrm{~kg} \mathrm{ha}^{-1}$ of NPK (10-20-20) as base fertilizer, $90 \mathrm{~kg} \mathrm{ha}^{-1}$ of $\mathrm{N}$ in the form of urea (45 $\% \mathrm{~N}$ ), to ensure soil coverage, in full tillering and after each cut. Plant density was set to 3 million plants per hectare. The cutting management system was established during the vegetative period, and applied to plants with a mean height of $30 \mathrm{~cm}$, and at $10 \mathrm{~cm}$ from the soil level, for regrowth purposes (MARTIN et al., 2010).

Seeds were sown in 20-L polyethylene vessels that were filled with soil (A1 horizon), classified as Solodic Haplic Eutrophic Planosol, belonging to the Pelotas mapping unit - RS (STRECK et al., 2008). The soil physical and chemical properties were as follows: $\mathrm{pH}\left(\mathrm{H}_{2} \mathrm{O}\right)$ : 5.4; $\mathrm{P}: 15.5 \mathrm{mg} \mathrm{dm} \mathrm{d}^{-3}$; $\mathrm{K}: 54 \mathrm{mg}$ $\mathrm{dm}^{-3}$; Ca: 2.8 cmolc. $\mathrm{dm}^{-3}$; Mg: 0.5 cmolc. $\mathrm{dm}^{-3} ; \mathrm{Al}$ : 0.4 cmolc. dm ${ }^{-3}$; Fe: $1,400 \mathrm{mg} \mathrm{dm}^{-3}$; Cu: $0.3 \mathrm{mg} \mathrm{dm}^{-}$ 3. Zn: $0.9 \mathrm{mg} \mathrm{dm}^{-3}$; Mn: $27.0 \mathrm{mg} \mathrm{dm}^{-3}$; CTC: 6.0 cmolc. $\mathrm{dm}^{-3}$; base saturation: $54 \%$; organic matter: $1.4 \%$; clay: $15 \%$.

In a previous experiment, soil was amended as indicated by the chemical analysis and based on the Manual of Fertilization and Liming for the States of Rio Grande do Sul and Santa Catarina (CQFS $\mathrm{RS} / \mathrm{SC}, 2004)$. The basic fertilization comprised $0.015 \mathrm{~kg} \mathrm{~m}^{3} \mathrm{~N}, 0.035 \mathrm{~kg} \mathrm{~m}^{3} \mathrm{P}$, and $0.023 \mathrm{~kg} \mathrm{~m}^{3} \mathrm{~K}$. Triple super phosphate and potassium chloride were used as urea sources. The coverage fertilization was performed at the beginning of the tillering and comprised $0.078 \mathrm{~kg} \mathrm{~m}^{3} \mathrm{~N}$. The plants were manually irrigated to meet the water demand of the crop.

Four plants were maintained per vessel, and each plant had one replicate. The experimental design was completely randomized in a factorial scheme, with four managements for seed production (without cut, and with one, two, and three cuts), and eight planting seasons $(10,20,30,40,50,60,70$, and 80 days after emergency [DAE]).

The plants were harvested at regular intervals of 10 DAE. Sampling was performed by collecting the whole plant, with subsequent separation into different structures, such as leaves, stem, roots, and spikes. To determine dry-mass, the samples of 
different plant parts were packed in brown-paper envelopes and subsequently subjected to forced ventilation drying at $70 \pm 2{ }^{\circ} \mathrm{C}$ until constant mass was achieved. The dry-mass content was measured using a $0.001 \mathrm{~g}$ precision scale. A LiCor LI-3 100 area meter was used to determine the leaf area $\left(\mathrm{L}_{\mathrm{a}}\right)$, and the results were expressed in square meters $\left(\mathrm{m}^{2}\right)$.

The leaf area index (L) was calculated using the formula: $\mathrm{L}=\mathrm{L}_{\mathrm{a}} / \mathrm{S}_{\mathrm{t}}$, where $\mathrm{L}_{\mathrm{a}}$ is the leaf area and $S_{t}$ is the surface area of the vessel occupied by the plant. Primary data of the cumulative total drymass $\left(\mathrm{W}_{\mathrm{t}}\right)$ were adjusted using the simple logistic equation: $\mathrm{W}_{\mathrm{t}}=\mathrm{W}_{\mathrm{m}} /\left(1+\mathrm{Ae}^{-\mathrm{Bt}}\right)$, where $\mathrm{W}_{\mathrm{m}}$ is the asymptotic maximum growth rate; $\mathrm{A}$ and $\mathrm{B}$, adjustment constants; e, the Napierian logarithm; and $t$, the time in DAE (RICHARDS, 1969).

The primary data of leaf area $\left(\mathrm{L}_{\mathrm{a}}\right)$, leaf $\left(\mathrm{W}_{1}\right)$, stem $\left(\mathrm{W}_{\mathrm{s}}\right)$, roots $\left(\mathrm{W}_{\mathrm{r}}\right)$ and spike $\left(\mathrm{W}_{\mathrm{spi}}\right)$ dry-mass were adjusted using orthogonal polynomials (RICHARDS, 1969). The values of the total drymass production rate $\left(\mathrm{C}_{\mathrm{t}}\right)$ were obtained through time derivatives of the adjusted equations of total dry-mass (W) (RADFORD, 1967). Instantaneous values of relative growth rate $\left(R_{w}\right)$ were determined using the following equation: $\mathrm{R}_{\mathrm{w}}=1 / \mathrm{W}_{\mathrm{t}} \cdot \mathrm{d}_{\mathrm{w}} / \mathrm{d}_{\mathrm{t}}$, , whereas instantaneous values of net assimilation rate $\left(\mathrm{E}_{\mathrm{a}}\right)$, leaf area ratio $\left(\mathrm{L}_{\mathrm{r}}\right)$, and leaf mass ratio $\left(\mathrm{L}_{\mathrm{w}}\right)$ were estimated using the following equations: $\mathrm{E}_{\mathrm{a}}=1 / \mathrm{L}_{\mathrm{a}} \cdot \mathrm{d}_{\mathrm{w}} / \mathrm{d}_{\mathrm{t}} ; \mathrm{L}_{\mathrm{r}}=\mathrm{L}_{\mathrm{a}} / \mathrm{W}_{\mathrm{t}} ; \mathrm{L}_{\mathrm{w}}=\mathrm{W}_{\mathrm{l}} / \mathrm{W}_{\mathrm{t}}$ (RADFORD, 1967).

The harvest index (HI) was determined using the equation: $\mathrm{HI}=\mathrm{W}_{\mathrm{s}} / \mathrm{W}_{\mathrm{t}}$, where $\mathrm{W}_{\mathrm{s}}$ corresponds to the seed dry-mass and $\mathrm{W}_{\mathrm{t}}$ is the total dry-mass of the plant. The conversion efficiency of the solar energy $(\xi)$ was determined by the equation: $\xi(\%)=\left(100 . C_{t} . \delta\right) / S_{r}$, where $\mathrm{S}_{\mathrm{r}}$ is the mean value of incident solar radiation (cal m${ }^{-2}$ day $^{-1}$ ) 10 days prior to the corresponding $\mathrm{C}_{\mathrm{t}}$ and $\delta$ is the calorific value of $4421.61 \mathrm{cal} \mathrm{g}^{-1}$ (DEMIRBAS, 2003).

The dry-mass partitioning among different plant parts (roots, stem, leaves, and spikes) throughout the development of the plants was determined, separately, based on the measurement of the mass allocated to each plant part followed by the conversion to the percentage of mass allocation for each organ using the primary data.

Seedling emergence was evaluated by sowing 400 seeds per treatment, which were distributed in eight replicates of 50 seeds each, arranged in polyethylene trays and soil. Observations were made 21 days after sowing, and the results are expressed as the percentage of emerged seedlings. The emergence speed index was determined based on daily counts of the number of emerged seedlings at least 3-4 mm in height. The counts were performed until a constant number of seedlings emerged.

Data regarding the emergence and emergence speed index were subjected to analysis of variance, and if the values were significant at $5 \%$ level, they were compared by the F test, and adjusted by orthogonal polynomials. Primary data of total drymass; leaf area; and dry-mass of stems, roots, and spikes were subjected to analysis of variance at $5 \%$ probability. Data for growth were evaluated based on the simple logistic equation (LOPES; LIMA, 2015).

The analysis of variance showed a significant interaction between the cutting management systems and the harvest dates of the plants with regard to the characters of leaf area $\left(\mathrm{L}_{\mathrm{a}}\right)$, leaf $\left(\mathrm{W}_{\mathrm{l}}\right)$, stem $\left(\mathrm{W}_{\mathrm{s}}\right)$, roots $\left(\mathrm{W}_{\mathrm{r}}\right)$, and spike $\left(\mathrm{W}_{\mathrm{spi}}\right)$ dry-mass, at $5 \%$ probability of error by the $\mathrm{F}$ test. For the variables seedling emergence and emergence speed index, the data showed significance at the $5 \%$ probability level by the F test; hence, the results were expressed using orthogonal polynomials.

In all treatments, total dry-mass $\left(\mathrm{W}_{\mathrm{t}}\right)$ production of dual-purpose wheat plants was adjusted to the logistic trend, with a high coefficient of determination $\left(\mathrm{R}^{2} \geq 0.96\right)$ (Figure $\left.1 \mathrm{c}\right)$. The initial growth was slow in plants of all treatments up to $40 \mathrm{DAE}$ and was followed by a phase of intense growth, reaching the maximum $\mathrm{W}_{\mathrm{t}}$ at $80 \mathrm{DAE}$ (Figure $1 \mathrm{C}$ ). After $40 \mathrm{DAE}$, 
the plants with one, two, and three cuts showed an increase in $\mathrm{W}_{\mathrm{t}}$ values until 60 DAE $(123 \%, 6 \%$, and $31 \%$, respectively), compared to those without cutting. However, from the 60 DAE time point, the $\mathrm{W}_{\mathrm{t}}$ values showed an inverse trend. The maximum values were observed in plants from seeds produced without cutting management (527.78 $\left.\mathrm{g} \mathrm{m}^{-2}\right)$, followed by those from seeds produced under one cut $\left(515.61 \mathrm{~g} \mathrm{~m}^{-2}\right)$, three cuts $\left(328.97 \mathrm{~g} \mathrm{~m}^{-2}\right)$, and two cuts $\left(269.09 \mathrm{~g} \mathrm{~m}^{-2}\right)$. According to Demétrio et al. (2012), oat plants subjected to different cutting management systems increase dry-mass production in relation to the absence of this management.

The reduction of leaf area influences the dynamics of growth rate, expansion of leaf area, interception of solar radiation, and conversion of carbohydrates into dry-mass, affecting total drymass production capacity and tillers formation (HARRISON et al., 2011). It should be noted that the reduced production of total dry-mass at the beginning of the plant development cycle is a common feature, which is attributable to the small leaf area. However, as the development cycle progresses, the total dry-mass production begins to increase as the area of the leaves available for the photosynthetic process gradually increases, and the radiation observed during the crop development cycle becomes higher (Figure 1b).

The maximum dry-mass production rates $\left(\mathrm{C}_{\mathrm{t}}\right)$ were obtained at $65 \mathrm{DAE}$, in plants subjected to cuts during seed production and at 70 DAE, in plants without cuts during the seed production management, which denotes a temporal-quantitative difference between the two treatment values (Figure 1d). The highest values of $C_{t}$ were noted in plants produced by seeds of plants not subjected to cutting management $\left(20.31 \mathrm{~g} \mathrm{~m}^{-2} \mathrm{~d}^{-1}\right)$, followed by seedlings produced with one cut $\left(14.43 \mathrm{~g} \mathrm{~m}^{-2} \mathrm{~d}^{-1}\right)$, three cuts $\left(10.89 \mathrm{~g} \mathrm{~m}^{-2} \mathrm{~d}^{-1}\right)$, and two cuts $\left(8.45 \mathrm{~g} \mathrm{~m}^{-2} \mathrm{~d}^{-1}\right)$.

The increase observed in $C_{t}$ values for plants originating from seeds produced in the absence of cutting management may be related to the higher content of reserves in the stem during the vegetative period, which can be reassimilated and distributed to the other parts of the plant. The increases in the values of the dry-mass production rate are related to the foliar increase, the amount of photoassimilates synthesized, and their distribution among the different organs of the plants (LOPES; LIMA, 2015). On the other hand, the reduction in the rates of dry-mass production may be related to the increase of the self-shading, non-photosynthetic tissues, and increase in leaf senescence (PEDÓ et al., 2015).

The maximum values of relative growth rate $\left(\mathrm{R}_{\mathrm{w}}\right)$ were observed at $10 \mathrm{DAE}$ with a systematic decrease until the end of the plant cycle (Figure 1e). The highest values of $\mathrm{R}_{\mathrm{w}}$ were observed in plants originating from seeds produced by plants subjected to three $\left(0.231 \mathrm{~g} \mathrm{~g}^{-1} \mathrm{~d}^{-1}\right)$ and two cuts $\left(0.1353 \mathrm{~g} \mathrm{~g}^{-1} \mathrm{~d}^{-1}\right)$. In contrast, plants originating from seeds produced without cutting management and those subjected to one cut management showed a similar $\mathrm{R}_{\mathrm{w}}$ response up to 10 DAE. From 60 DAE, plants originating from seeds produced by plants without cuts showed higher values until the end of the cycle. Throughout the development cycle, it is possible that the plants, regardless of the treatment, showed lower dry-mass allocation than that was pre-existing. However, up to $60 \mathrm{DAE}$, greater capacity of dry-mass deposition compared to the existing value was observed in plants subjected to two- and three-cut management systems.

Figure 1. Maximum and minimum temperatures (a), 
solar radiation (b), total dry-mass (c), dry-mass production rate (d), relative growth rate (e), net assimilation rate (f), leaf area index (g), and efficiency of solar energy conversion (h) in dual-purpose wheat cultivars originating from seeds produced from different cutting management systems, where: no cut (-); one cut (---); two cuts (‥) and three cuts (---).
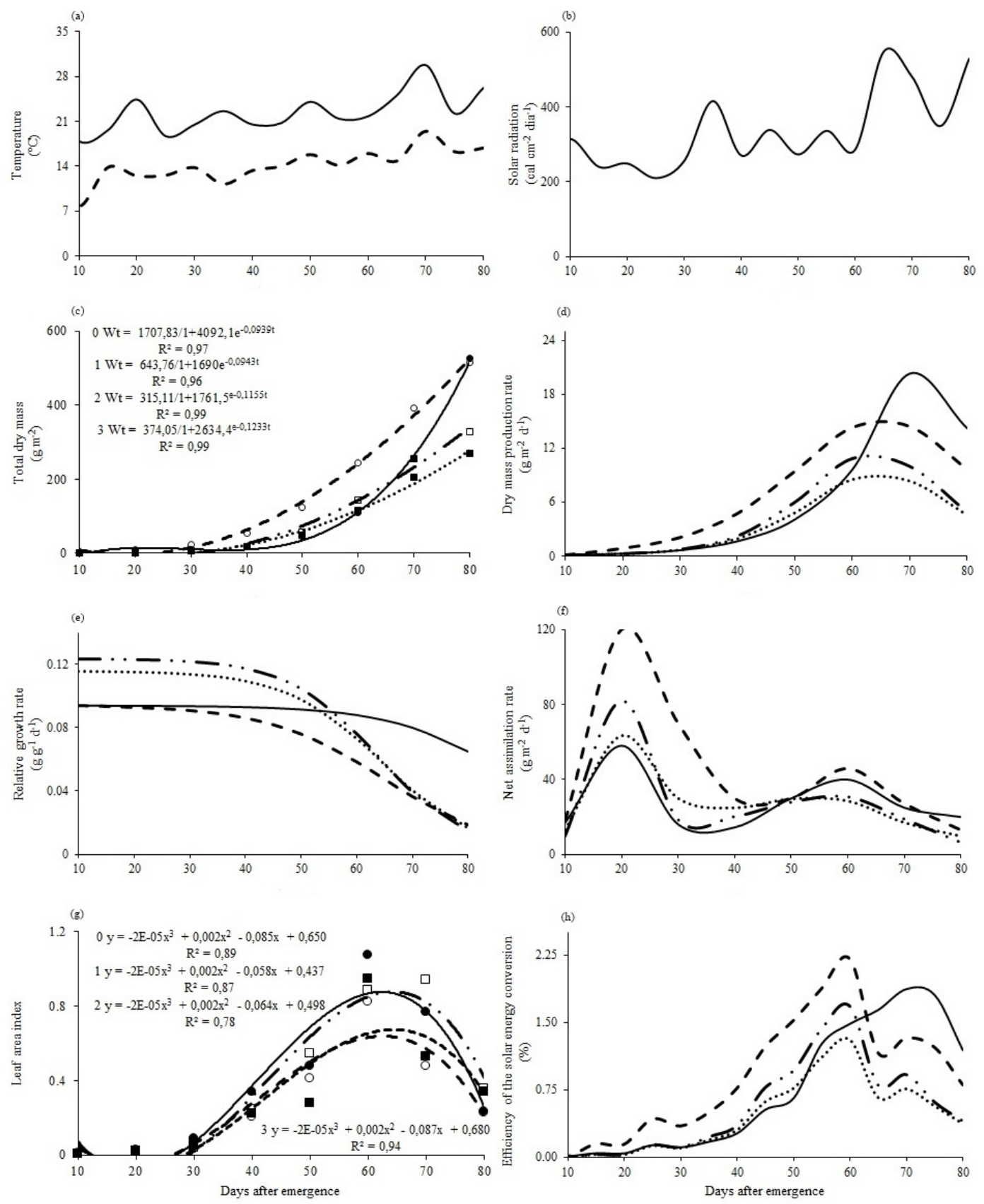

The high values noted at the beginning of the plant cycle may be explained by the fact that the leaf area was primarily constituted by young leaves, which have a high photosynthetic capacity and growth rate (AUMONDE et al., 2011). In contrast, the reduction of $\mathrm{R}_{\mathrm{w}}$ values during the plant cycle was related to the gradual increase of nonphotosynthetic tissues, due to increased respiratory activity and self-shading (PEDÓ et al., 2015). 
The curves of the net assimilation rate $\left(\mathrm{E}_{\mathrm{a}}\right)$ presented two peaks of maximum production during the crop cycle of wheat plants. The first peak of $\mathrm{E}_{\mathrm{a}}$ was observed at $20 \mathrm{DAE}$ for plants under all treatments (Figure 1f). However, higher values were observed for plants subjected to cuts during the seed production management compared to those subjected to treatments without cuts. There was an increase of $107 \%, 9 \%$, and $41 \%$ for plants subjected to one-, two-, and three-cut treatments, respectively. The second peak of $\mathrm{E}_{\mathrm{a}}$ occurred at 60 DAE in plants of all treatments, and may be explained by the appearance of the reproductive organs, and preferential metabolic drain with high mobilization capacity of assimilates (AUMONDE et al., 2011).

The net assimilation rate $\left(\mathrm{E}_{\mathrm{a}}\right)$ was higher in plants originating from seeds of plants subjected to the cutting management systems, demonstrating greater efficiency in the allocation of total dry-mass for a given area of leaves (Figure 1f). The results obtained are justified by the higher photosynthetic efficiency of the leaf area, reduction of growth rates, and increase in the vegetative period (HARRISON et al., 2010, 2011).

The leaf area index (L) was adjusted to the cubic equation because it characterizes the leaf area more precisely throughout the development cycle. The occurrence of a small leaf area at the beginning of the development cycle is common; this is typically followed by period of high leaf formation and expansion, and then by senescence and leaf fall (LOPES; LIMA, 2015). The maximum values were obtained at 60 DAE for plants from seeds produced without cut management and with three cuts. Plants from seeds produced with one and two cuts reached the maximum values at 70 DAE (Figure 1g), with a subsequent decrease. On the other hand, the conversion efficiency of the solar energy $(\xi)$ was higher in plants originating from seeds produced by plants under cutting management. Plant responses of all treatments increased up to 60 DAE (Figure 1h), with a later decline until the end of the cycle.
Plants obtained from seeds produced in one-, two-, and three-cu treatments reached the maximum values of $\xi$ of $2.2 \%, 1.3 \%$, and $1.6 \%$, respectively (Figure 1h). Plants obtained from seeds produced in the absence of cut management reached their maximum $(1.8 \%)$ at $70 \mathrm{DAE}$. The efficiency of conversion of solar energy increased in conjunction with $C_{t}$ (Figure 1d). Moreover, in dual-purpose wheat cultivars, the higher efficiency of conversion of solar energy is influenced by the interception of light from the canopy of the plants, foliar area, and photosynthetically active radiation available, considering the available leaf area (Figure 1g) (HARRISON et al., 2011).

The dry-mass partitioning was similar compared to that observed in plants generated from seeds produced without cutting, and those under onecut and two-cut management systems (Figure 2). Initially, allocation of dry-mass was the highest in leaves, followed by that in roots and stems. From 60 DAE, assimilated allocation in these plants was observed to have reduced verified, and the preferential metabolic drain changed for spikes and seeds.

Plants from seeds produced under the management of three cuts (Figure 2d) showed altered allocation of dry-mass in relation to those from the other treatments. This fact is evidenced by the higher allocation of assimilates in roots during the initial phase, until 30 DAE. On the other hand, the allocation of dry-mass in spikes was reduced in plants subjected to three cuts compared to those subjected to the other treatments.

The highest allocation of dry-mass in the roots is fundamental in the initial establishment of grazing plants, and also in the process of recovering the leaves after cutting or grazing (HARRISON et al., 2011). The differences in the dry-mater partitioning between plants from various seed production management systems could be attributed to the efficiency with which the plants intercept solar radiation, assimilate the photosynthetically active 
radiation, and thus convert it into morphological and reproductive structures (HARRISON et al., 2011). In addition, as the cutting management influences the size of the leaf area and modifies the production of assimilates and their deposition in the seeds, it may affect the seed vigor and initial physiological performance in the production field (PESKE et al., 2012).

Figure 2. Dry-mass partitioning between different morphological structures of dual-purpose wheat cultivars originating from seeds produced (a) without cutting management, one cut (b), two cuts (c), and three cuts (d). Emergence of seedlings in substrate (e) and emergence speed index of plants (f) originating from seeds produced under one, two, and three cuts.
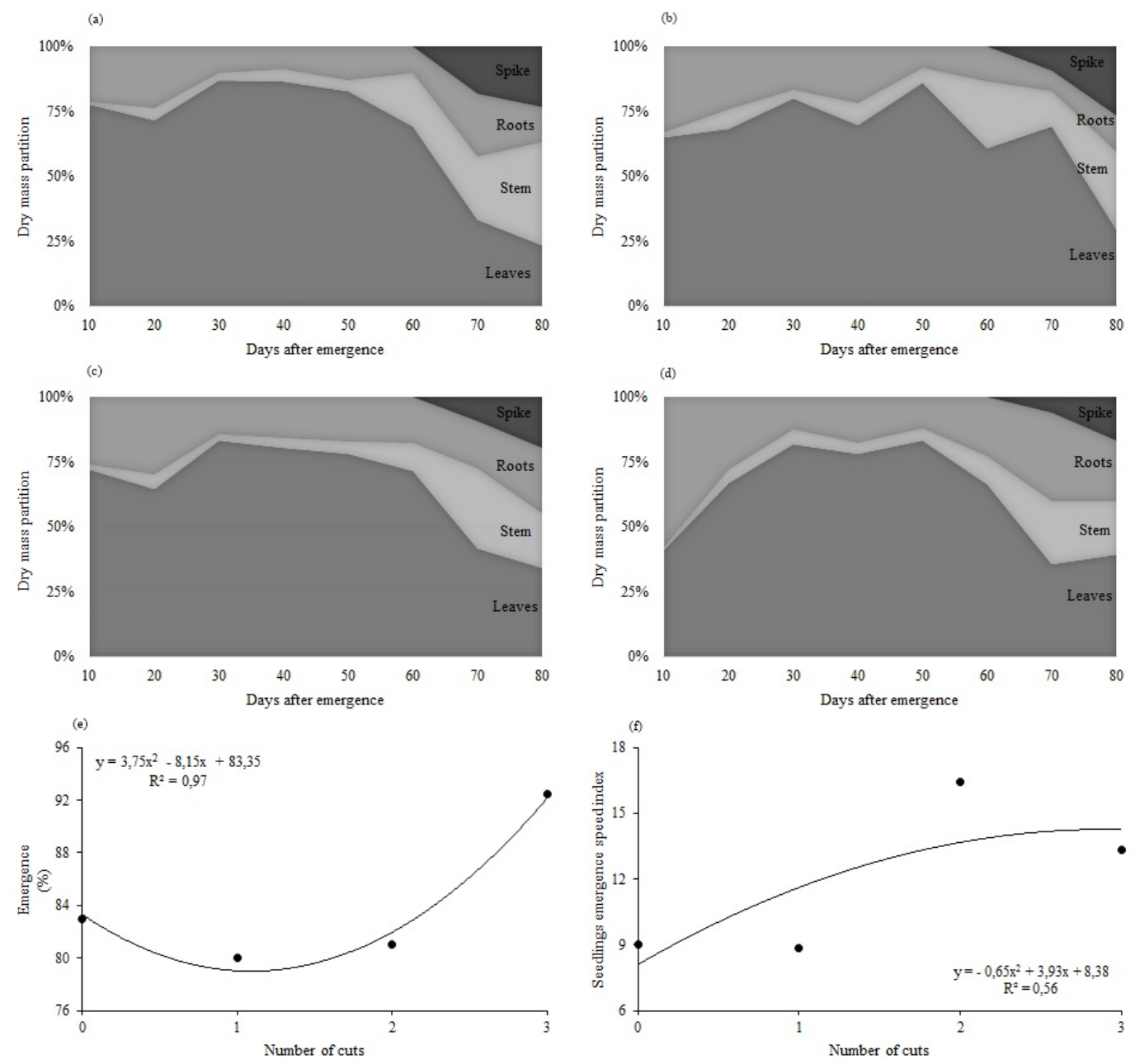

The emergence of seedlings in the substrate was adjusted to the quadratic model, with a high coefficient of determination $\left(\mathrm{R}^{2} \geq 0.98\right)$. The highest values of emergence were obtained for seeds from the three-cut treatment during, with a $10.7 \%$ increase in relation to the treatment without cuts (Figure 3a). Similarly, the rate of emergence was also adjusted to the quadratic model, showing an increasing

trend in values from the one-cut treatment during the management of seed production (Figure $3 b$ ). Thus, it is indicative that the increase in the number of cuts, provided superior seed quality in terms of vigor.

The higher vigor evidenced in seeds produced with the three-cut management, as verified by the 
higher values of seedling emergence and emergence speed index, indicates a greater efficiency in the reorganization of the membrane systems, hydrolysis, and allocation of seedling sources (PESKE et al., 2012). These physiological responses may be related to the fact that plants subjected to cutting have reduced stature and lower nesting rates, which possibly results in a more efficient targeting of assimilates to the seeds. It is worth noting that plants subjected to cutting during the vegetative period depend on higher nutrient inputs, mainly $\mathrm{N}$, to recover the leaf area extracted after the cutting (HASTENPFLUG et al., 2011).

In general, plants originating from seeds produced without cut management showed higher growth rates, which may be verified by the higher allocation of total dry-mass, dry-mass production rate, and relative growth rate. On the other hand, plants originating from seeds produced by plants under cutting management had a higher net assimilation rate. However, when the quality of the seeds was evaluated, plants originating from the three-cut treatment showed greater seed vigor, as evidenced by the emergence tests and emergence index.

Dual-purpose wheat cultivars originating from seeds produced in the absence of cutting presented higher allocation of total dry-mass, dry-mass production rate, and relative growth rate. The net assimilation rate was higher in plants originating from seeds produced with cutting management. Finally, plants produced from seeds subjected to the three-cut production management resulted in more vigorous seeds.

\section{Acknowledgment}

The present study was supported by $\mathrm{CNPq}$, National Council for Scientific and Technological Development - Brazil.

\section{References}

AUMONDE, T. Z.; LOPES, N. F.; MORAES, D. M.; PEIL, R. M. N.; PEDÓ, T. Análise de crescimento do híbrido de mini melancia Smile ${ }^{\circledR}$ enxertada e não enxertada. Interciência, Caracas, v. 36, n. 9, p. 677-681, 2011.

COMISSÃO DE QUÍMICA E FERTILIDADE DO SOLO - CQFS. Manual de adubação e calagem para os Estados do Rio Grande do Sul e Santa Catarina. Sociedade Brasileira de Ciência do Solo. 10. ed. Porto Alegre: Comissão de Química e Fertilidade do Solo, 2004. $400 \mathrm{p}$.

COMPANHIA NACIONAL DE ABASTECIMENTO - CONAB. Acompanhamento da safra brasileira: grãos, primeiro levantamento. Brasília: Conab, 2015. Disponível em: <http://www.conab.gov.br/OlalaCMS/ uploads/arquivos/15_10_28_17_24_01_boletim_graos_ outubro_2015.pdf $>$. Acesso em: 24 out. 2015.

DEMÉTRIO, V. J.; COSTA, T. C. A.; OLIVEIRA, R. S. P. Produção de biomassa de cultivares de aveia sob diferentes manejos de corte. Pesquisa Agropecuária Tropical, Goiânia, v. 42, n. 2, p. 198-205, 2012.

DEMIRBAS, A. Relationships between lignin contents and fixed carbon contents of biomass samples. Energy Conversion and Management, Oxford, v. 44, n. 9, p. 1481-1486, 2003.

FORSTHOFER, E. L.; SILVA, P. R.F.; STRIEDER, M. L.; MINETTO, T.; RAMBO, L.; ARGENTA, G.; SANGOI, L.; SUHRE, E.; SILVA, A. A. Desempenho agronômico e econômico do milho em diferentes níveis de manejo e épocas de semeadura. Pesquisa Agropecuária Brasileira, Brasília, v. 41, n. 3, p. 399-407, 2006.

GONDIM, T. C. O.; ROCHA, V. S.; SEDIYAMA, C. C.; MIRANDA, G. V. Análise de trilha para componentes do rendimento e caracteres agronômicos de trigo sob desfolha. Pesquisa Agropecuária Brasileira, Brasília, v. 43, n. 4, p. 487-493, 2008.

HARRISON, M. T.; EVANS, J. R.; DOVE, H.; MORRE, A. D. Dual-purpose cereals: can the relative influences of management and environment on crop recovery and grain yield be dissected? Crop \& Pasture Science, Canberra, v. 62, n. 11, p. 930-946, 2011.

HARRISON, M. T.; KELMAN, W. M.; MOORE, A. D. Grazing winter wheat relieves plant water stress and transiently enhances photosynthesis. Functional Plant Biology, Canberra, v. 37, n. 8, p. 726-736, 2010. 
HASTENPFLUG, M.; BRAIDA, J. A.; MARTIN, T. N.; ZIECH, M. F.; SIMIONATTO, C. C.; CASTAGNINO, D. S. Cultivares de trigo duplo propósito submetidos ao manejo nitrogenado e a regimes de corte. Arquivo Brasileiro de Medicina Veterinária e Zootecnia, Belo Horizonte, v. 63, n. 1, p. 196-202, 2011.

LOPES, N. F.; LIMA, M. G. de S. Fisiologia da produção vegetal. Viçosa, MG: Editora UFV, 2015. 492 p.

MARTIN, T. N.; SIMIONATTO, C. C.; BERTONCELLI, P.; ORTIZ, S.; HASTENPFLUG, M.; ZLECH, M. F.; SOARES, A. B. Fitomorfologia e produção de cultivares de trigo duplo propósito em diferentes manejos de corte e densidades de semeadura. Ciência Rural, Santa Maria, v. 40, n. 8, p. 1695-1701, 2010.

PEDÓ, T.; MARTINAZZO, E. G.; AUMONDE, T. Z.; VILLELA, F. A. Plant growth analysis and seed vigor expression: effects of soil waterlogging during rye plant development. Acta Botanica Brasilica, Belo Horizonte, v. 29, n. 1, p. 1-7, 2015.
PESKE, S. T.; VILLELA, F. A.; MENEGHELLO, G. E. Sementes: fundamentos científicos e tecnológicos. 3. ed. Pelotas: Editora e Gráfica da UFPel, 2012. 573 p.

RADFORD, P. J. Growth analysis formulae: their use and abuse. Crop Science, Madison, v. 7, n. 3, p. 171-175, 1967.

RICHARDS, F. J. The quantitative analysis of growth. In: STEWWARD, F. C. (Ed.). Plant physiology. A treatise. New York: Academic Press, 1969. p. 3-76.

STRECK, E. V.; KÄMPF, N.; DALMOLIN, R. S. D.; KLAMT, E.; NASCIMENTO, P. C.; SCHNEIDER, P.; GIASSON, E.; PINTO, L. F. S. Solos do Rio Grande do Sul. 2. ed. Porto Alegre: EMATER/RS; UFRGS, 2008. $222 \mathrm{p}$. 